\title{
EVALUATION OF THE POTENTIAL OF SOILS AROUND OYI RIVER, TAKETE-ISAO, NIGERIA FOR IRRIGATION
}

\author{
Babalola Temitope Seun \\ Kabba College of Agriculture \\ Division of Agricultural Colleges \\ Ahmadu Bello University, Nigeria
}

\author{
Alemoru Matthew Oladele \\ Kabba College of Agriculture \\ Division of Agricultural Colleges \\ Ahmadu Bello University, Nigeria
}

\begin{abstract}
Irrigation is important for round year production of food to guarantee food security of the increasing population. The potential of three soil units (YA, YB and YC) around Oyi River in Takete-Isao, Nigeria was evaluated for surface, sprinkler and drip irrigation systems using the parametric approach of irrigation suitability evaliuation. Soil unit YA has suitability index of $46.17,54.66$ and 64.13 with suitability class ratings of S3 (marginally suitable) and S2 (moderately suitable) for the three irrigation systems respectively. YB was 38.30 and rated N1- currently not suitable for surface irrigation while $Y C$ is rated moderately suitable with suitability index of 63.18 and 76.00 for sprinkler and drip irrigation systems respectively. Post-harvest residue management, land tillage across slope and construction of contour bunds, incorporation of organic manure, maintenance of vegetative cover and cultivation of cover crops were recommended.
\end{abstract}

Keywords - irrigation, suitability, evaluation, drip, sprinkler, surface

\section{INTRODUCTION}

There is growing concern over food security in Africa and especially sub-Saharan Africa [1]. Productivity is declining in rain-fed agriculture globally [2]. To double food production over the next two decades, water has been considered as the most important component for the transformation of low productive rain-fed agriculture into most effective and efficient irrigated agriculture [2,3].

Irrigation is viewed as a key factor in progress towards achieving food security in Africa. However, while nearly $40 \%$ of the world's agricultural production comes from irrigated land [4], only 4 per cent (6 million ha) of the sub-Saharan African total cultivated area is irrigated [5].

Food crops production in Nigeria comes mainly from rain-fed smallholder agriculture, therefore rainfall is one of the most important factor in food supply. The dependence on rain by most of small holder farmers largely contributed to low-output and inability to meet the food supply of the fast growing population [6]. The high dependency on rain-fed farming and erratic rainfall require alternative ways of improving agricultural production in Sub-Saharan African region [6].

Today food production via irrigated agriculture does not correspond to the current rapid population growth. Soil salinity and contamination in addition to the excessive urban development are also the main factors that affect the state of food production by irrigated agriculture [7]. In Nigeria irrigation technology is low. The total irrigation potential of Nigeria is about 3.14 million hectare, 1.10 million hectares for public irrigation projects and 2.04 million hectares for fadama irrigation projects [8]. Only about four percent of the cultivated land area in Nigeria is under irrigation. Estimated irrigated cropland varies from one source to the other but its total water managed area is estimated to be a little over 950,000 ha. These yield about $10 \%$ of the national crop yield [8].

According to [9], the irrigation of more land is necessity for world food security. To develop a sustainable irrigation system, it is required to know the limitations and potentials of the land [10]. It is a prerequisite that the suitability of soils be assessed for irrigation before such a project is undertaken. Global food security and stability depends on the management of the natural resources such as river basins. The efficient management of river basins has been identified as solution to problems of agricultural productivity [11] in that most of the soils are productive and can support cultivation of crops all year round $[11,12]$ therefore the evaluation of suitability of soils at the basin of Oyi river along Itakete Isao-Isanlu, Nigeria for sprinkler, surface and drip irrigation systems was considered.

\section{MATERIALS AND METHODS}

\subsection{Description of the study area}

The study was carried at Warshull Integrated Farms Limited which covered an area of 80 hectares on $08^{\circ} 10^{\prime} 21^{\prime \prime} \mathrm{N}$ and $05^{\circ} 29^{\prime} 41^{\prime \prime} \mathrm{E}$ at the basin of Oyi River along Itakete-Isao/Isanlu road, Yagba East Local Government, Kogi State, Nigeria. 


\section{International Journal of Engineering Applied Sciences and Technology, 2020 \\ Vol. 5, Issue 1, ISSN No. 2455-2143, Pages 92-97 \\ Published Online May 2020 in IJEAST (http://www.ijeast.com)}

The area has climate typical of humid tropics with rainfall that spans the month of April to November with the peak in June to September. The dry season extends from December to March. The mean annual rainfall is $1337.55 \mathrm{~mm}$, mean annual temperature is $33^{\circ} \mathrm{C}$ and mean annual relative humidity is $70 \%$.

The vegetation of the area is dominated by tall grasses, trees and shrubs. Farming activities in the area is predominantly on subsistence bases in which farmers cultivate yam, cassava, rice, sesame, beniseed, cowpea, maize and vegetables.

\subsection{Field work}

The soil units within the area were identified using the rigid grid method following the guidelines of Soil Survey Staff [13]. The soil units were identified and delineated with texture and colour. Three soil units were identified and labeled YA, YB and YC. Soil profiles were dug in areas where soil units are identified. The profiles were described and soil samples collected for laboratory analysis. The effective soil depth, drainage and slope were measured directly at the field following the method of FAO [14].

\subsection{Laboratory analysis}

The electrical conductivity EC was determined using (1:2.5 ratio of soil : water) suspension. The texture of the soil was determined by the hydrometer method [15]. $\mathrm{CaCo}_{3}, \mathrm{pH}$, organic carbon (\%), total nitrogen (\%) available $\mathrm{P}$ (ppm) exchangeable bases $(\mathrm{Cmol} / \mathrm{kg})$ exchangeable acidity $(\mathrm{Cmol} / \mathrm{kg})$ were determined following the International Institute for Tropical Agriculture guidelines [16]. The effective cation exchange capacity, base saturation and exchange sodium percentage were calculated.

\subsection{Irrigation suitability procedure}

To evaluate the land suitability for irrigation, the parametric evaluation system of Sys [17, 18] were applied using soil and land characteristics

These characteristic include environmental factors, drainage properties, soil physical and chemical properties. They were rated and used to calculate the capability index for irrigation $\mathrm{Ci}$ according to the formula:

$\mathrm{Ci}=\mathrm{A} \times \underline{B} \times \underline{\mathrm{C}} \times \underline{\mathrm{D}} \times \underline{\mathrm{E}} \times \underline{\mathrm{F}}$

$$
100100 \quad 100 \quad 100 \quad 100
$$

Where $\mathrm{Ci}=$ suitability index for irrigation

$\mathrm{A}=$ Rating of soil texture $\mathrm{B}=$ Rating of soil depth $\mathrm{C}=$

Rating of $\mathrm{CaCO}_{3}$ status

$\mathrm{D}=$ Electrical Conductivity

$\mathrm{E}=$ Drainage rating
Table 1 : Suitability Index for Irrigation Suitability Indices Ci classes

\begin{tabular}{llll}
\hline Capability Index & Class & Definition & Symbol \\
\hline$>80$ & I & Highly suitable & $\mathrm{S}_{1}$ \\
$60-80$ & II & Moderately suitable & $\mathrm{S}_{2}$ \\
$45-60$ & III & Marginally suitable & $\mathrm{S}_{3}$ \\
$30-45$ & IV & Currently not suitable & $\mathrm{N}_{1}$ \\
$<30$ & V & Permanently not & $\mathrm{N}_{2}$ \\
\hline
\end{tabular}
Source: Sys [17]

Table 2: Rating of soil depth for irrigation

\begin{tabular}{llll}
\hline $\begin{array}{l}\text { Soil } \\
\text { depth } \\
{[\mathrm{cm}]}\end{array}$ & $\begin{array}{l}\text { Rating for } \\
\text { surface } \\
\text { Irrigation }\end{array}$ & $\begin{array}{l}\text { Rating for } \\
\text { sprinkler } \\
\text { Irrigation }\end{array}$ & $\begin{array}{l}\text { Rating for } \\
\text { drip } \\
\text { Irrigation }\end{array}$ \\
\hline$<20$ & 25 & 30 & 35 \\
& & & \\
$20-50$ & 60 & 65 & 70 \\
$50-80$ & 80 & 85 & 90 \\
$80-100$ & 90 & 95 & 100 \\
$>100$ & 100 & 100 & 100 \\
\hline
\end{tabular}

Table 3: Rating of $\mathrm{CaCO} 3$ for irrigation

\begin{tabular}{llll}
\hline $\mathrm{CaCO} 3$ & $\begin{array}{l}\text { Rating for } \\
\text { surface } \\
\text { Irrigation }\end{array}$ & $\begin{array}{l}\text { Rating for } \\
\text { sprinkler } \\
\text { Irrigation }\end{array}$ & $\begin{array}{l}\text { Rating for } \\
\text { drip } \\
\text { Irrigation }\end{array}$ \\
\hline$<0.3$ & 90 & 90 & 90 \\
$0.3-10$ & 95 & 95 & 95 \\
$10-25$ & 100 & 100 & 95 \\
$25-50$ & 90 & 90 & 80 \\
$>50$ & 80 & 80 & 70 \\
\hline
\end{tabular}

Table 4: Rating of salinity for irrigation

\begin{tabular}{|c|c|c|c|c|c|c|}
\hline \multirow{2}{*}{$\begin{array}{l}\mathrm{EC} \\
{[\mathrm{ds}} \\
\mathrm{m}- \\
1]\end{array}$} & \multicolumn{2}{|c|}{$\begin{array}{l}\text { Rating for surface } \\
\text { Irrigation }\end{array}$} & \multicolumn{2}{|c|}{$\begin{array}{l}\text { Rating for } \\
\text { sprinkler } \\
\text { Irrigation }\end{array}$} & \multicolumn{2}{|c|}{$\begin{array}{l}\text { Rating for drip } \\
\text { Irrigation }\end{array}$} \\
\hline & $\begin{array}{l}\mathrm{C}, \mathrm{SiC}, \\
\mathrm{SiCL}, \mathrm{S}, \\
\mathrm{SC} \\
\text { Textures }\end{array}$ & $\begin{array}{l}\text { Other } \\
\text { Textures }\end{array}$ & $\begin{array}{l}\mathrm{C}, \mathrm{SiC}, \\
\mathrm{SiCL}, \\
\mathrm{S}, \\
\mathrm{SC} \\
\text { textures }\end{array}$ & $\begin{array}{l}\text { Other } \\
\text { Textures }\end{array}$ & $\begin{array}{l}\text { C, SiC, } \\
\text { SiCL, } \\
\text { S, } \\
\text { SC } \\
\text { textures }\end{array}$ & $\begin{array}{l}\text { Other } \\
\text { Textures }\end{array}$ \\
\hline$<4$ & 100 & 100 & 100 & 100 & 100 & 100 \\
\hline $4-8$ & 90 & 95 & 95 & 95 & 95 & 95 \\
\hline $\begin{array}{l}8- \\
16\end{array}$ & 80 & 50 & 85 & 50 & 85 & 50 \\
\hline $\begin{array}{l}16- \\
30\end{array}$ & 70 & 30 & 75 & 35 & 75 & 35 \\
\hline$>30$ & 60 & 20 & 65 & 20 & 65 & 25 \\
\hline
\end{tabular}


Table 5: Rating of drainage classes for irrigation

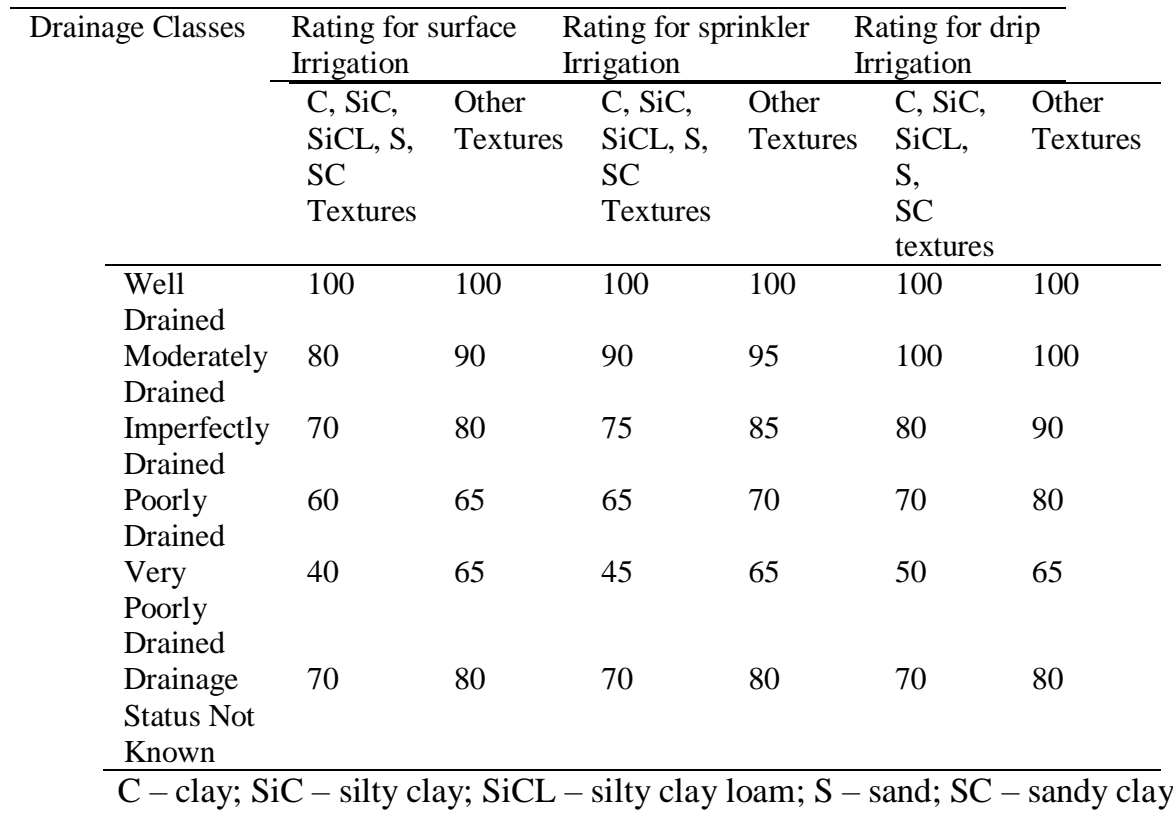

Table 6: Rating of slope for irrigation

\begin{tabular}{lllllll}
\hline $\begin{array}{l}\text { Slope classes } \\
{[\%]}\end{array}$ & $\begin{array}{l}\text { Rating for surface } \\
\text { Irrigation }\end{array}$ & $\begin{array}{l}\text { Rating for sprinkler } \\
\text { Irrigation }\end{array}$ & $\begin{array}{l}\text { Rating for drip } \\
\text { Irrigation }\end{array}$ \\
\cline { 2 - 6 } & non-terraced & Terraced & non-terraced & terraced & non-terraced & terraced \\
\hline $0-1$ & 100 & 100 & 100 & 100 & 100 & 100 \\
$1-3$ & 95 & 95 & 100 & 100 & 100 & 100 \\
$3-5$ & 90 & 95 & 95 & 100 & 100 & 100 \\
$5-8$ & 80 & 90 & 85 & 95 & 90 & 100 \\
$8-16$ & 70 & 80 & 75 & 85 & 80 & 90 \\
$16-30$ & 50 & 65 & 55 & 70 & 60 & 75 \\
$>30$ & 30 & 45 & 35 & 50 & 40 & 55 \\
\hline
\end{tabular}

Table 7: Rating of Textural Classes for Irrigation

\begin{tabular}{|c|c|c|c|c|c|c|c|c|c|c|c|c|c|c|c|}
\hline \multirow[t]{3}{*}{ Tex } & \multicolumn{5}{|c|}{ Rating for Surface Irrigation } & \multicolumn{5}{|c|}{ Rating for Sprinkler Irrigation } & \multicolumn{5}{|c|}{ Rating for Drip Irrigation } \\
\hline & \multicolumn{3}{|c|}{ Fine gravel (\%) } & \multicolumn{2}{|c|}{$\begin{array}{l}\text { Coarse gravel } \\
(\%)\end{array}$} & \multicolumn{3}{|c|}{ Fine gravel (\%) } & \multicolumn{2}{|c|}{$\begin{array}{l}\text { Coarse gravel } \\
(\%)\end{array}$} & \multicolumn{3}{|c|}{ Fine gravel (\%) } & \multicolumn{2}{|c|}{$\begin{array}{l}\text { Coarse gravel } \\
(\%)\end{array}$} \\
\hline & $\begin{array}{l}< \\
15\end{array}$ & $\begin{array}{l}15- \\
40\end{array}$ & $\begin{array}{l}40- \\
75\end{array}$ & $15-40$ & $40-75$ & $\begin{array}{l}< \\
15\end{array}$ & $\begin{array}{l}15- \\
40\end{array}$ & $\begin{array}{l}40- \\
75\end{array}$ & $15-40$ & $40-75$ & $\begin{array}{l}< \\
15\end{array}$ & $\begin{array}{l}15- \\
40\end{array}$ & $\begin{array}{l}40- \\
75\end{array}$ & $15-40$ & $40-75$ \\
\hline $\mathrm{CL}$ & 100 & 90 & 80 & 80 & 50 & 100 & 90 & 80 & 80 & 50 & 100 & 90 & 80 & 80 & 50 \\
\hline SiL & 100 & 90 & 80 & 80 & 50 & 100 & 90 & 80 & 80 & 50 & 100 & 90 & 80 & 80 & 50 \\
\hline SCL & 95 & 85 & 75 & 75 & 45 & 95 & 85 & 75 & 75 & 45 & 95 & 85 & 75 & 75 & 45 \\
\hline $\mathrm{L}$ & 90 & 80 & 70 & 70 & 45 & 90 & 80 & 70 & 70 & 45 & 90 & 80 & 70 & 70 & 45 \\
\hline SiL & 90 & 80 & 70 & 70 & 45 & 90 & 80 & 70 & 70 & 45 & 90 & 80 & 70 & 70 & 45 \\
\hline $\mathrm{Si}$ & 90 & 80 & 70 & 70 & 45 & 90 & 80 & 70 & 70 & 45 & 90 & 80 & 70 & 70 & 45 \\
\hline $\mathrm{SiC}$ & 85 & 95 & 80 & 80 & 40 & 85 & 95 & 80 & 80 & 40 & 85 & 95 & 80 & 80 & 40 \\
\hline C & 85 & 95 & 80 & 80 & 40 & 85 & 95 & 80 & 80 & 40 & 85 & 95 & 80 & 80 & 40 \\
\hline $\mathrm{SC}$ & 80 & 90 & 75 & 75 & 35 & 95 & 90 & 80 & 75 & 35 & 95 & 90 & 85 & 80 & 35 \\
\hline $\mathrm{SL}$ & 75 & 65 & 60 & 60 & 35 & 90 & 75 & 70 & 70 & 35 & 95 & 85 & 80 & 75 & 35 \\
\hline LS & 55 & 50 & 45 & 45 & 25 & 70 & 65 & 50 & 55 & 30 & 85 & 75 & 55 & 60 & 35 \\
\hline S & 30 & 25 & 25 & 25 & 25 & 50 & 45 & 40 & 30 & 30 & 70 & 65 & 50 & 35 & 35 \\
\hline
\end{tabular}




\section{International Journal of Engineering Applied Sciences and Technology, 2020 \\ Vol. 5, Issue 1, ISSN No. 2455-2143, Pages 92-97 \\ Published Online May 2020 in IJEAST (http://www.ijeast.com)}

\section{RESULTS AND DISCUSION}

\subsection{Physico-chemical properties of the soils}

The laboratory analysis results of the soils surface $(0-40 \mathrm{~cm}$ depth) of the three soil units identified are presented in Table 8.

The soils were moderately sandy to highly sandy with percentage sand range of $49-75 \%$. Soil unit YA is sandy clay loam, YB is Loam and YC is sandy loam textured. The sandy loam and loamy sand texture indicates that there has been some degree of removal of fine soil particles by surface runoff and it implies that there is potential for the soil to be eroded and leached of nutrients if left open for a long period of time. It also indicates the well to moderately drained condition of the soils. The effective soil depth was $56 \mathrm{~cm}$ as a result of hard pan at soil unit YA while it was $63 \mathrm{~cm}$ and $102 \mathrm{~cm}$ at units $Y C$ and YD as result of water table. The high water table at the dry period of the year (Januray) indicates that the soils units have high potential for irrigation agricultural production.

The $\mathrm{pH}$ of the soils ranged from 5.42 to 6.10 . The $\mathrm{pH}$ values are rated [19] strongly acidic to slightly acidic, deficiency of nutrient in the soil units is not likely and response to fertilizer/soil amendment will be high.

The organic matter content ranged from 2.50 to $4.90 \%$. These values are considered to be moderate and adequate for crop production. Organic matter is very important to soil fertility and nutrient availability.

The total Nitrogen values range of 3.30 to $6.01 \mathrm{~g} / \mathrm{kg}$ are high. The values are above the range of $2 \mathrm{~g} / \mathrm{kg}$ of soil recommended by Federal Ministry of Agriculture for an ideal Nigerian soil [20]. It followed that same trend with organic matter; the use of leguminous crops in the cropping will help to maintain nitrogen level of the soils.

The available phosphorus values 22.19 to $35.44 \mathrm{ppm}$ are high and above the critical levels. The values are optimum for crop production.

The calcium $(\mathrm{Ca})$ is the most abundant among the cations (bases), the values recorded $(2.31-3.53 \mathrm{cmol} / \mathrm{kg})$ are low. Magnesium $(\mathrm{Mg})$ content $(1.07-1.8 \mathrm{cmol} / \mathrm{kg})$ is moderate, potassium $(\mathrm{K})(0.71-1.10 \mathrm{cmol} / \mathrm{kg})$ is high and sodium $(\mathrm{Na})$ $(0.39-0.67 \mathrm{cmol} / \mathrm{kg})$ is moderate [21]. There are no serious intensive crop production activities in the farm soil and most of the land area is under cover, therefore there has not been serious depletion of nutrients. There will be need for improved fertility management scheme to prevent the decline of these nutrients because they are easily depleted under intensive cultivation, improve their levels in the soils and availability to cultivated crops.

Table 8: Physico-chemical properties of the soil units

\begin{tabular}{cccc}
\hline Soil & \multicolumn{4}{c}{ Soil units } \\
\cline { 2 - 4 } properties & YA & YB & YC \\
\hline $\mathrm{pH}(\mathrm{H} 2 \mathrm{O})$ & 6.10 & 5.60 & 5.42
\end{tabular}

\begin{tabular}{|c|c|c|c|c|}
\hline $\mathrm{OM}$ & $\%$ & 2.50 & 3.60 & 4.90 \\
\hline $\mathrm{TN}$ & $\mathrm{g} / \mathrm{kg}$ & 3.30 & 4.18 & 6.01 \\
\hline AP & Ppm & 22.19 & 35.44 & 28.60 \\
\hline $\mathrm{Ca}^{2+}$ & $\mathrm{Cmol} / \mathrm{kg}$ & 3.53 & 2.31 & 2.70 \\
\hline $\mathrm{Mg}^{2+}$ & $\mathrm{Cmol} / \mathrm{kg}$ & 1.07 & 1.18 & 1.13 \\
\hline $\mathrm{K}^{+}$ & $\mathrm{Cmol} / \mathrm{kg}$ & 1.09 & 0.72 & 1.10 \\
\hline $\mathrm{Na}^{+}$ & $\mathrm{Cmol} / \mathrm{kg}$ & 0.56 & 0.58 & 0.53 \\
\hline EA & $\mathrm{Cmol} / \mathrm{kg}$ & 0.39 & 0.59 & 0.67 \\
\hline ECEC & $\mathrm{Cmol} / \mathrm{kg}$ & 6.64 & 5.38 & 6.13 \\
\hline BS & $\%$ & 94.13 & 89.03 & 89.07 \\
\hline $\mathrm{CaCO}_{3}$ & $\%$ & 4.64 & 3.06 & 3.45 \\
\hline AWH & $\%$ & 29.10 & 41.32 & 38.45 \\
\hline $\mathrm{EC}$ & $\underset{1}{\mathrm{mmh} / \mathrm{cm}^{-}}$ & 0.79 & 0.92 & 0.82 \\
\hline Sand & & 63 & 49 & 75 \\
\hline Silt & $\%$ & 16 & 31 & 06 \\
\hline Clay & $\%$ & 21 & 20 & 19 \\
\hline Texture & & SCL & $\mathrm{L}$ & SL \\
\hline Drainage & & $\begin{array}{c}\text { Moderately } \\
\text { drained }\end{array}$ & $\begin{array}{l}\text { Moderately } \\
\text { drained }\end{array}$ & $\begin{array}{c}\text { Well } \\
\text { drained }\end{array}$ \\
\hline Slope & $\%$ & 3.1 & 4.7 & 2.72 \\
\hline $\begin{array}{c}\text { Other } \\
\text { bservations }\end{array}$ & & $\begin{array}{l}\text { Fe-mn } \\
\text { concretion, } \\
\text { effective } \\
\text { depth } \\
56 \mathrm{~cm}\end{array}$ & $\begin{array}{c}\text { Water } \\
\text { table at } \\
63 \mathrm{~cm}\end{array}$ & $\begin{array}{l}\text { Water } \\
\text { table at } \\
102 \mathrm{~cm}\end{array}$ \\
\hline
\end{tabular}

OM=organic matter $\quad T N=$ total nitrogen, $A P=$ available phosphorus, $C a=$ calcium, $M g=$ magnesium, $K=$ potassium, $\mathrm{Na}=$ sodium, EA=exchangeable acidity, $B S=$ percentage base saturation, $S L=$ sandy loam, $S C L=$ sandy clay loam, $L=L o a m$ The effective cation exchange capacities are moderate. The values ranged from 5.38 to $6.64 \mathrm{cmol} / \mathrm{kg}$ of soil at the surface. This value is low but typical of most Nigeria soils [22]. This indicates that the soils have low plant nutrient reserves therefore soil management efforts should be geared towards improving nutrient reserves of the soil.

The percentage base saturation value is high. The values are higher than $70 \%$ and it indicates that the soils high cation concentration in the exchange complex and implies that there is no threat of soil acidity to crop production in the area.

Soil unit YA has iron and manganese concretions, this could harden irreversibly if the soil is exposed for a long time to form hardpan and rendered the soil uncultivable.

\subsection{Irrigation suitability evaluation}

The three soil units of the study area were evaluated for surface, sprinkler and drip irrigation systems. The suitability index values and class ratings are presented in table 9.

In the evaluation of soils for surface irrigation, soil unit YA and $\mathrm{YC}$ are have suitability index values $(\mathrm{Ci})$ of 46.17 and 


\section{International Journal of Engineering Applied Sciences and Technology, 2020 \\ Vol. 5, Issue 1, ISSN No. 2455-2143, Pages 92-97 \\ Published Online May 2020 in IJEAST (http://www.ijeast.com)}

48.74 respectively and they are rated into suitability class S3marginally suitable. Soil unit YC has $\mathrm{Ci}$ of 38.30 and was rated currently not suitable, this implies that the soils require some management measures to make it suitable for surface irrigation.

The evaluation for sprinkler irrigation showed an improvement in ratings of soil unit $\mathrm{YB}$ and $\mathrm{YC}$ than the surface irrigation. Soil unit $\mathrm{YB}$ and $\mathrm{YC}$ are rated S3marginally suitable and S2- moderately suitable with ci values of 45.64 and 63.18 respectively.

In the evaluation for drip irrigation system, soil units YA and YC are rated S2- moderately suitable with ci of 64.13 and 76.00 respectively. YB is S3- marginally suitable with ci of 53.87 respectively.

All the soil units are placed in classes lower than S1- highly suitable as a result of texture, soil depth and slope ratings. These properties conditioned the soils to be rated below S1.

Texture is an important soil property to irrigation in that, it determines to a large extent permeability, infiltration and water holding capacity of soils [11]. The soils of the study area are coarse textured therefore water and nutrient losses will be high.

Soil depth influences irrigation management decisions. It determines rooting depth and available soil water which in turns determine the frequency of irrigation. Soil depth was critical at YA and YB.

Slope relates to runoff, soil drainage, erosion, use of machinery and choice of crops. The slope percentages recorded in all the soil units are not ideal for surface irrigation system. This reflected in the lower suitability class rating of soil units for surface irrigation.

Table 9: Suitability index values $(\mathrm{Ci})$ and suitability classes of the irrigation methods

\begin{tabular}{|c|c|c|c|c|c|c|}
\hline \multirow[t]{2}{*}{$\begin{array}{l}\text { Mapping } \\
\text { unit }\end{array}$} & \multicolumn{2}{|c|}{ Surface irrigation } & \multicolumn{2}{|c|}{$\begin{array}{l}\text { Sprinkler } \\
\text { irrigation }\end{array}$} & \multicolumn{2}{|r|}{$\begin{array}{l}\text { Drip irrigation } \\
2012 \text {. }\end{array}$} \\
\hline & $\mathrm{Ci}$ & $\begin{array}{l}\text { Suitability } \\
\text { classes }\end{array}$ & $\mathrm{Ci}$ & $\begin{array}{l}\text { Suitability } \\
\text { classes }\end{array}$ & $\mathrm{Ci}$ & $\begin{array}{l}\text { Suitfli]likebede, T. and Ademe, Y. Evaluating land suitability for } \\
\text { classifsigation purpose in Abaya district, Borena zone, Ethiopia. }\end{array}$ \\
\hline YA & 46.17 & S3 & 54.66 & S3 & 64.13 & S2 African Journal of Agricultural Research, Volume 11, Issue \\
\hline YB & 38.30 & N1 & 45.64 & S3 & 53.87 & S3 \\
\hline $\mathrm{YC}$ & 48.74 & S3 & 63.18 & S2 & 76.00 & [7] Kipchirchir, T.S. Evaluation of the suitability of soils for \\
\hline \multicolumn{3}{|c|}{$\begin{array}{l}\text { S2- Moderately suitable } \\
\text { Currently not suitable }\end{array}$} & Margina & ly suitable & $N 1-$ & $\begin{array}{l}\text { irrigation in lower kuja, nyatike district, Kenya. A Research } \\
\text { Project Report Submitted in Partial Fulfillment of the } \\
\text { Requirements for the Degree of Master of Arts (M.A) in } \\
\text { Environmental Planning and Management of the University of } \\
\text { Nairobi, pg. 136. (2012). }\end{array}$ \\
\hline
\end{tabular}

\section{CONCLUSION AND RECOMMENDATION}

The soils of the study area are marginal in terms of fertility and require soil management measures to maintain and raise the fertility status of the soil units. Soil units YA and YC are the most suitable for irrigation. Sprinkler irrigation system is most suitable for soil unit YC and drip irrigation system is the suitable for soil unit YA and YC.

Post-harvest residue management, land tillage across slope and construction of contour bunds, incorporation of organic manure, maintenance of vegetative cover and cultivation of cover crops are therefore recommended.

\section{REFERENCES}

[1] Bousquet, M., Faurès, J., Frenken, K. and Verelst, L. Assessment of irrigation potential

in Africa Arc-Info: A tool For the computation of the irrigation water requirements at continental level. Remote Sensing and Water Resources pg. 115-126. (1998)

[2] Mandal, B., Dolui, G. and Satpathy, S. Land suitability assessment for potential surface irrigation of river catchment for irrigation development in Kansai watershed, Purulia, West Bengal, India. (2017).

[3] FAO (Food and Agricultural Organization). Irrigation potential in Africa: a basin approach FAO Land and Water Bulletin, 4. Paper No. 56 Rome, Italy. (1997)

[4] Albaji, M., Landi, A., Nasa, B. S. and Moravej, K. Land suitability evaluation for surface

and drip irrigation in Shavoor plain, Iran. Journal of Applied Science Volume 8 Issue4 pg. 654-659 (2008).

[5] Kadigi, R.M.J., Tesfaye, G., Bizoza, A. and Zinabou, G. Irrigation and water use efficiency in sub-Saharan Africa". GPN-Agriculture Policy Series. Briefing paper number 4, . 


\section{International Journal of Engineering Applied Sciences and Technology, 2020 \\ Vol. 5, Issue 1, ISSN No. 2455-2143, Pages 92-97 \\ Published Online May 2020 in IJEAST (http://www.ijeast.com)}

[8] Fasina A.S., Awe G.O. and Aruleba, J.O. Irrigation Suitability Evaluation

and Crop Yield - An Example with Amaranthus cruentus in Southwestern Nigeria. African

Journal of Plant Science, Volume 2 Issue 7, pg. 61-66. (2008).

[9] Dengiz, O. A comparison of different irrigation methods based on the parametric evaluation approach. Turk J. Agric. For. Volume 30, pg. 21-29. (2006).

[10] Kasa Teka, Van Rompaey, A. and Poesen, J. Land suitability assessment for different irrigation methods in Korir Watershed, Northern Ethiopia. Journal of the Drylands, Volume 3 Issue 2, pg. 214-219. (2010).

[11] Fasina, A.S. Irrigation suitability of Asu river basin soils, south eastern Nigeria. International Journal of Soil Sciences, Volume 3, Issue 1, pg. 35-41. (2008)

[12] Singh, B.R. and Babaji, G.A. Characteristics of soils of Dundaye District I. The soils of the university dry land farm. Nigeria Journal of Basic and Applied Science, Volume 3, pg. 7-16. (1989).

[13] Soil Survey Staff. Soil Survey Field and Laboratory Methods Manual. Soil Survey Investigations Report No. 51, Version 2.0. R. Burt and Soil Survey Staff (ed.). U.S. Department of Agriculture, Natural Resources Conservation Service. (2014).

[14] FAO (Food and Agricultural Organization). Guidelines for soil description.4th ed. Viale delle Terme di Caracalla. Rome, Italy. (2006).

[15] Gee, G.W. and Bander J.W. Particle Size Analysis Part I. Physical and Mineralogical Method. Pp 404-408. Madison. Wisconsin. U.S.A. (1980).

[16] IITA (International Institute of Tropical Agriculture). Selected Methods of Soil and Plant Analysis. IITA Manual series, I IITA Ibadan 60pp. (1979).

[17] Sys C. Land Evaluation. International Training Centre for Postgraduate Soil Scientist Vol, 1,2 and 3. State University Ghent. (1985).

[18] Sys C., Van Ranst E. and Debaveye J. Land evaluation. Part $1 . \quad$ Principles in land evaluation and crop production calculations. International Trai ning Center for Post-graduate Soil Scientist, University Ghent. (1991).

[19] Bargrizan, S., Smernik, R. and Mosley, L.M. Development of a spectrophotometric method for determining $\mathrm{pH}$ of soil extracts and comparison with glass electrode measurements. Soil Science Society of America Journal, Volume 81,pg. 1350-1358. (2017).

[20] FMANR (Federal Ministry of Agriculture and Natural Resources). Literature review on soil fertility investigations in Nigeria. Number 5, pg. 252-261. (1990).

[21] FAO (Food and Agricultural Organization). A provisional methodology for land degradation assessment. FAO, Rome, Italy. (2004).

[22] Babalola, T.S. Pedogenesis of soils derived from different parent materials in two Agro ecological zones of Nigeria (Unpublished) $\mathrm{PhD}$. Thesis, Ekiti State University, Nigeria. pg.288. (2018). 